\title{
Analisis Persiapan Fisik Pendakian Gunung Ijen Dan Gunung Ranti Di Kabupaten Banyuwangi
}

\section{Analysis Of The Physical Preparation For The Astress Of Mount Ijen And Mountain Ranti In Banyuwangi District}

\author{
Farid Prasetyo Manggala Putra ${ }^{1}$, Puji Setyaningsih ${ }^{2}$, Danang Ari Santoso ${ }^{3}$
}

${ }^{1,2,3}$ Program Studi Pendidikan Jasmani Kesehatan dan Rekreasi, Universitas PGRI Banyuwangi Jl. Ikan Tongkol No. 22 Kertosari Banyuwangi

Email : trifatma2728@gmail.com ${ }^{1}$, myedu37@gmail.com², danangarisantoso@ gmail.com³

\begin{abstract}
ABSTRAK
Gunung ijen merupakan gunung merapi aktif yang terletak dalam 2 wilayah yaitu kabupaten banyuwangi dan kabupaten bondowoso. Sedangkan gunung ranti adventure yang terletak 50 meter sebelum paltuding apabila ditembuh dari arah banyuwangi. Gunung ijen meliki ketinggian 2386 mdpl dengan medan pendakiannya yang sudah dibuat lebar dengan panjang rute 3,4 Km. Gunung ranti merupakan sebuah gunung dengan ketinggian 2600 mdpl memiliki medan pendakian setapak dan berpasir dengan panjang rute $3.5 \mathrm{~km}$. Penelitian ini menggunakan metode deskriptif. dengan teknik pengambilan datanya menggunkan non-probality sampling berupa (accidental sampling) Teknik pengumpulan datanya berupa kuesioner. Hasil penelitian menunjukan bahwa terdapat $79 \%$ dan $69,23 \%$ responden yang mendaki gunung ijen dan ranti melakukan persiapan fisik berupa aktifitas fsik, 68\% dan 53,84\% responden melakukan persiapan fisik dengan intensitas latian, $79 \%$ dan $88,46 \%$ responden melakukan persiapan berupa latihan daya tahan aerobik, 57\% responden di ijen tinkat kesadaran diri akan latihan fisik anaerobiknya rendah dan $53,84 \%$ responden diranti terdapat persiapan fisik berupa latihan daya tahan anaerobik. hal ini juga menunjukkan persiapan fisik yang sesuai pada pendakian gunun ijen diantaranya adalah latihan fisik aerobik karena sesuai dengan topografi medan pendakian yang lebar dan asab belerang. Dan pada pendakian gunung ranti persipan yang cocok berupa latihan fisik aerobik dan anaerobik.
\end{abstract}

\section{Kata kunci: Aktifitas Fisik, Olahraga, Pendakian Gunung}

\begin{abstract}
Mount Ijen is an active volcano located in 2 areas, namely Banyuwangi Regency and Bondowoso Regency. Meanwhile, Mount Ranti Adventure, which is located 50 meters before Paltuding, when it is recovered from Banyuwangi. Mount Ijen has an altitude of 2386 meters above sea level with the climbing terrain that has been made wide with a route length of $3.4 \mathrm{~km}$. Mount Ranti is a mountain with an altitude of 2600 meters above sea level and has a sandy hiking trail with a route length of $3.5 \mathrm{~km}$. This research uses a descriptive method. with the data collection technique using non-probability sampling in the form (accidental sampling) The data collection technique is in the form of a questionnaire. The results showed that there were $79 \%$ and $69.23 \%$ of respondents who climbed Mount Ijen and Ranti did physical preparation in the form of physical activities, $68 \%$ and $53.84 \%$ of respondents did physical preparation with
\end{abstract}


training intensity, $79 \%$ and $88.46 \%$ of respondents did preparation in the form of aerobic endurance training, $57 \%$ of respondents in Ijen had a low level of self-awareness of anaerobic physical exercise and $53.84 \%$ of respondents in diranti had physical preparation in the form of anaerobic endurance training. This also shows the appropriate physical preparation for climbing Mount Ijen, including aerobic physical exercise because it is in accordance with the wide topography of the climbing terrain and sulfuric acid. And in climbing the mountain, the suitable preparation is aerobic and anaerobic physical exercises.

\section{Keywords: Physical Activity, Sports, Mountaineering}

\section{PENDAHULUAN}

Aktivitas hubungannya sangat erat dengan kegiatan manusia dalam kesehariannya, karena setiap orang pasti melakukan aktivitas dalam satu hari selama orang tersebut masih hidup. Menurut Baharudin dan Hartoto (2016) aktivitas fisik merupakan suatu aktifitas gerakan yang mengeluarkan tenaga, guna memelihara kebugaran, mental, dan kesehatan jasmani maupun rohani yang biasa dilakukan sehari hari dimanapun dan kapanpun. Sedangkan Welis dan Rifki (2013) aktifitas fisik merupakan fungsi dasar hidup manusia. Jadi dengan kata lain aktifitas adalah kegiatan yang dilakukan dalam kehidupan sehari-hari guna untuk melanjutkan hidup sehat. Dengan melakukan aktifitas fisik juga dapat menambah pola hidup sehat manusia pada kehidupan sehari-hari.

Manusia dengan segala kesibukan serta berbagai macam kegiatan dan aktifitas. Dengan aktifitas sehari-hari yang padat membuat waktu luang yang ada digunakan untuk olahraga. Karena olahraga menjadi gaya hidup dan kebutuhan mendasar dalam menjaga kesehatan, kondisi tubuh jasmani dan rohani. Bahkan kegiatan berolahraga dilakukan dengan berbagai upaya untuk meningkatkan aktifitas fisik bahkan untuk mencapai tujuan prestasi. Menurut Sandi (2019) olahraga merupakan suatu kegiatan terstuktur dan terencana yang bertujuan untuk meperbaiki kinerja fisik. Hal senada disampaikan oleh Bangun (2016) olahraga adalah kegiatan pelatihan jasmani, yaitu kegiatan jasmani untuk memperkaya dan meningkatkan kemampuan serta gerak dasar maupun gerak keterampilan (kecabangan olahraga). Dengan melakukan kegiatan berolahraga, tentu dapat menjadikan tubuh seseorang sehat jasmani maupun rohani dan dapat membentuk manusia yang berkualitas.

Olahraga mendaki gunung sekarang ini menjadi kegemaran masyarakat dan banyak para penggiat pecinta alam yang untuk melakukan kegiatan penjelajahan alam. Bahkan pendakian gunung sekarang ini juga sebagai media liburan. Banyak 
orang memilih menghabiskan liburannya dengan pendaki gunung, hingga ada beberapa film yang mengisahkan kegiatan perjuangan dalam mendaki gunung. Seperti gunung semeru dan gunung rinjani. Ardianto dkk (2015) kegiatan mendaki gunung merupakan salah satu kegiatan berolahraga dialam bebas yang cukup banyak digemari dan memerlukan pengalaman, latihan peralatan, kekuatan mental, fisik, pengetahuan tentang alam serta mampu melakukan persiapan kegiatan dengan baik.

Pramudya dan Hidaya (2017) mendaki gunung adalah suatu perjalanan yang melewati medan pegunungan yang memiliki tujuan seperti kegiatan ekspedisi, penelitian ilmiah, wisata, serta eksplorasi ke puncak- puncak yang sangat tinggi dan berbahaya, dalam bahasa inggris kegiatan mendaki gunung sering disebut mountaineering. Berdasarkan pemaparan di atas mendaki gunung merupakan salah satu sarana kegiatan di luar ruangan yang penuh petualangan serta hal-hal baru sambil beraktivitas berolahraga rekreasi dan sambil menikmati keindahan alam.

$$
\text { Lailissaum (2013) mengatakan }
$$

kegiatan mendaki gunung merupakan kegiatan yang berbahaya, tidak sedikit orang yang meninggal di gunung, sebelum mendaki gunung perlu mempersiapkan fisik, mental, dan perlu mempersiapkan informasi gunung yang akan didaki. Banyak pendaki gunung yang belum sadar akan hal ini sehingga mengakibatkan suatu pendakian terhambat karena kelelahan atau bahkan terjadi kecelakaan karena hilangnya konsentrasi saat melewati jalur yang curam karena staminanya telah habis (Nurajab, 2019).

Mengingat faktor kelelahan dalam kegiatan mendaki dapat mempengaruhi dalam sebuah pendakian maka perlu memperhatikan pentingnya mempersiapkan fisik dan perlengkapan dalam suatu kegiatan perjalanan, maka sebelum memulai kegiatan, sebaiknya terlebih dahulu mempersiapkan fisik dan sebuah check list (daftar perlengkapan). Namun apabila dalam sebuah pendakian bepergian dengan secara berkelompok maka pesiapan yang dibawa untuk kepentingan kelompok agar nantinya terhindar dari hal-hal yang tidak diinginkan.

Gunung ijen dan gunung ranti kini menjadi salah satu tujuan wisata olahraga mendaki gunung yang banyak digemari. Gunung ijen adalah sebuah gunung berapi yang meliki ketinggian $2386 \mathrm{mdpl}$ terdapat fenomena alam berupa api biru atau biasa disebut blue fire dan gunung ranti merupakan sebuah gunung dengan ketinggian $2600 \quad \mathrm{mdpl}$ memiliki 
pemandangan yang indah berupa matahari terbit seperti di atas awan. Dalam pendakian gunung ijen medan pendakiannya yang sudah dibuat lebar dengan panjang rute 3,4 $\mathrm{Km}$, tersedia juga kamar mandi dan fasilitas penyewaan masker. Sedangkan di gunung meranti sendiri medan pendakian pada pendakian gunung ranti tergolong jalan setapak dan berpasir dengan panjang rute $3.5 \mathrm{~km}$.

\section{METODE PENELITIAN}

Penelitian ini dirancang menggunakan metode kuantitatif yang bersifat deskriptif. Metode kuantitatif dipilih karena digunakan untuk meneliti populasi atau sampel tertentu, pengumpulan datanya berupa instrumen penelitian, analisis data berupa kuantitatif atau statistik. Sugiono (2014) Judul dengan bersifat deskriptif digunakan dengan maksud untuk menggambarkan keadaan satu atau lebih variabel secara mandiri. Dalam penelitian ini peneliti menggunakan satu variabel mandiri yaitu persiapan fisik pendakian gunung ijen dan gunung ranti.

Penelitian ini dimulai dengan melakukan observasi awal di lapangan sertamelakukan identifikasi masalah, kemudian melakukan penelitian tentang permsalahan yaitu persiapan fsik pendakian gunung ijen dan gunung meranti. Dalam pengambilandatanya dengan menggunakan kuesioner berupa petanyaan yang diberikan kepada responden. Dan hasil data yang didapat akan dianalisis dan didolah secara deskriptif Kuantitatif seta menyimpulkan data hasil penelitian.

Populasi adalah wilayah generaliasi yang terdiri atas: obyek atau subyek yang mempunyai kuantitas dan karakteristik tertentu yang yang ditetapkan oleh peneliti untuk mempelajari dan kemudian ditarik kesimpulannya (Sugiono, 2014). Sedangkan Populasi pada penelitian ini adalah para pendaki pada pendakian di gunung ijen dan meranti.

Sampel adalah bagian dari jumlah dan karakteristik yang dimiliki oleh populasi tersebut (Sugiono, 2014). Teknik dalam pengambilan sampel menggunakan nonprobality sampling (accidental sampling). Menurut Maksum (2012) non-probality sampling adalah adalah teknik-teknik sampling yang tidak memungkinkan setiap anggota memiliki peluang yang sama untuk menjadi sampling. Maksum (2012) Accidental sampling sampling adalah sebuah teknik sampling dimana sampel dikenakan kepada siapa saja yang kebetulan dijumpai 
peneliti saat mengadakan penelitian, asalkan ada hubungannya dengan penelitian.

Teknik pengumpulan data yang digunakan dalam penelitian ini yaitu menggunakan kuisioner dan wawancara yang disertakan dokumentasi. Dengan memberikan atau menyebarkan daftar pertanyaan kepada responden dengan harapan memberikan respon atas daftar pertanyaan tersebut.

Teknik analisis data yang yang digunakan dalam penelitian ini diarahkan untuk menjawab rumusan masalah. Teknik analisis data yang digunakan dalam dalam penelitian ini menggunakan statistik deskriptif, sugiono (2014) statistik deskriptif adalah statistik yang digunakan untuk menganalisis data dengan cara mendeskripsikan atau menggambarkan data yang telah terkumpul. Mengenai penyajian data akan ditampilkan secara tabel, grafik, ataupun diagram.

\section{HASIL DAN PEMBAHASAN}

Dari hasil penelitian yang telah dilakukan tentang persiapan fisik pendakian gunung ijen diketahui hasil pengukuran yang diikelompokkan kedalam aktifitas fisik diketahui hasil hitung dan pengolahan data berdasarkan rumus yang sudah ditentukan sebagai berikut:
Tabel 1. Deskripsi Kategori Hasil Analisis Aktivitas Fisik

\begin{tabular}{ccrrl}
\hline $\begin{array}{c}\text { N } \\
\text { o }\end{array}$ & $\begin{array}{c}\text { Kelas } \\
\text { Interval }\end{array}$ & $\begin{array}{c}\text { Freku } \\
\text { ensi }\end{array}$ & $\begin{array}{r}\text { Pros } \\
\text { enta } \\
\text { se }\end{array}$ & Kategori \\
\hline 1 & 15 s/d 20,2 & 4 & $4 \%$ & $\begin{array}{l}\text { Tidak } \\
\text { Pernah }\end{array}$ \\
\hline 2 & 20,3 s/d 25,5 & 17 & $\begin{array}{r}17 \\
\%\end{array}$ & $\begin{array}{l}\text { Hampir } \\
\text { Tidak } \\
\text { Pernah }\end{array}$ \\
\hline 3 & 25,6 s/d 30,8 & 34 & $\begin{array}{r}34 \\
\%\end{array}$ & $\begin{array}{l}\text { Kadang } \\
\text { Kadang }\end{array}$ \\
\hline 4 & 30,9 s/d 36,1 & 40 & $\begin{array}{r}40 \\
\text { Cukup } \\
\text { Sering }\end{array}$ \\
\hline 5 & 36,2 s/d 41,4 & 5 & $5 \%$ & Selalu \\
\hline & Total & $\mathbf{1 0 0}$ & $\begin{array}{r}\mathbf{1 0 0} \\
\text { \% }\end{array}$ & \\
\hline
\end{tabular}

Dari hasil Deskripsi Aktivitas fisik diatas dapat di ketahui Tingkat aktifitas persiapan fisik pendaki sebanyak sebanyak 4 orang memiliki prosentase $4 \%$ berada pada kategori sangat tidak pernah, 17 orang memiliki prosentse $17 \%$ berada pada kategori Hampir tidak Pernah, 34 orang dengan prosentase $34 \%$ berada pada kategori Kadang-kadang, 40 orang dengan prosentase $40 \%$ beradaa dalam kategori cukup sering, 5 orang dengan prosentase 5\% berada pada kategori selalu melakukan aktifitas fisik sebagai persiapan fisik sebelum mendaki gunung. Hasil hitung tabel aktifitas fisik ditampilkan berupa gambar diagram garis sebagai berikut: 
Dari hasil penelitian yang telah dilakukan tentang persiapan fisik pendakian gunung ijen diketahui hasil pengukuran yang dikelompokkan kedalam Intensitas latihan diketahui hasil hitung dan pengolahan data berdasarkan rumus yang sudah ditentukan sebagai berikut:

Tabel 2. Deskripsi Kategori Hasil Analsis Intensitas Latihan

\begin{tabular}{|c|c|c|c|c|}
\hline No & $\begin{array}{c}\text { Kelas } \\
\text { Interval }\end{array}$ & $\begin{array}{l}\text { Freq } \\
\text { uency }\end{array}$ & $\begin{array}{c}P e \\
r c \\
e n \\
t\end{array}$ & $\begin{array}{c}\text { Kategor } \\
\mathrm{i}\end{array}$ \\
\hline 1 & $2 \mathrm{~s} / \mathrm{d} 3,8$ & 4 & $\begin{array}{r}4 \\
\%\end{array}$ & $\begin{array}{l}\text { Tidak } \\
\text { Pernah }\end{array}$ \\
\hline 2 & $\begin{array}{c}3,9 \mathrm{~s} / \mathrm{d} \\
5,7\end{array}$ & 29 & $\begin{array}{r}29 \\
\%\end{array}$ & $\begin{array}{l}\text { Hampir } \\
\text { Tidak } \\
\text { Pernah }\end{array}$ \\
\hline 3 & $\begin{array}{c}5,8 \mathrm{~s} / \mathrm{d} \\
7,6\end{array}$ & 37 & $\begin{array}{l}37 \\
\%\end{array}$ & $\begin{array}{l}\text { Kadang } \\
\text { Kadang }\end{array}$ \\
\hline 4 & $\begin{array}{c}7,7 \mathrm{~s} / \mathrm{d} \\
9,5\end{array}$ & 26 & $\begin{array}{l}26 \\
\%\end{array}$ & $\begin{array}{l}\text { Cukup } \\
\text { Sering }\end{array}$ \\
\hline 5 & $\begin{array}{c}9.6 \mathrm{~s} / \mathrm{d} \\
11,4\end{array}$ & 4 & $\begin{array}{r}4 \\
\%\end{array}$ & Selalu \\
\hline & Total & 100 & $\begin{array}{r}10 \\
0 \\
\%\end{array}$ & Total \\
\hline
\end{tabular}

Dari hasi table 2 intensitas latihan diatas dapat diketahui Tingkat aktifitas persiapan fisik pendaki sebanyak sebanyak 4 orang memiliki prosentase $4 \%$ berada pada kategori sangat tidak pernah, 29 orang memiliki prosentse $29 \%$ berada pada kategori hampir tidak Pernah, 37 orang dengan prosentase $37 \%$ berada pada kategori kadang-kadang, 26 orang dengan prosentase $26 \%$ beradaa dalam kategori cukup sering, 4 orang dengan prosentase $4 \%$ berada pada kategori selalu melakukan Intensitas latihandengan terstruktur sebagai persiapan fisik sebelum mendaki gunung. Hasil hitung tabel tersebut ditampilkan berupa gambar diagram garis sebagai berikut.

Dari hasil penelitian yang telah dilakukan tentang persiapan fisik pendakian gunung ijen diketahui hasil pengukuran yang diikelompokkan kedalam persiapafisik data tahan aerobik diketahui hasil hitung dan pengolahan data berdasarkan rumus yang sudah ditentukan sebagai berikut:

\section{Tabel 3. Deskripsi Kategori Hasil Analsis} Daya Tahan Aerobik

\begin{tabular}{rrrrl}
\hline No & $\begin{array}{c}\text { Kelas } \\
\text { Interval } \\
1\end{array}$ & $\begin{array}{r}\text { Frek } \\
\text { uensi }\end{array}$ & $\begin{array}{c}\text { Perc } \\
\text { ent }\end{array}$ & Kategori \\
& $5 \%$ & $\begin{array}{l}\text { Tidak } \\
\text { Pernah }\end{array}$ \\
2 & 10 s/d 12 & 22 & $22 \%$ & $\begin{array}{l}\text { Hampir } \\
\text { Tidak } \\
\text { Pernah }\end{array}$ \\
& & & & \\
3 & 13 s/d 15 & 41 & $41 \%$ & $\begin{array}{l}\text { Kadang } \\
\text { Kadang }\end{array}$ \\
\hline 4 & 16 s/d 18 & 29 & $29 \%$ & $\begin{array}{l}\text { Cukup } \\
\text { Sering } \\
\end{array}$ \\
\hline 5 & 19 s/d 21 & 9 & $3 \%$ & Selalu \\
\hline & Total & $\mathbf{1 0 0}$ & $\mathbf{1 0 0}$ & \\
& & & $\mathbf{0}$ & \\
\hline
\end{tabular}

Dari hasil tabel diatas Persiapan Fisik daya tahan aerobik diatas dapat diketahui Tingkat aktifitas persiapan fisik pendaki sebanyak sebanyak 6 orang memiliki prosentase $6 \%$ berada pada kategori sangat 
tidak pernah, 22 orang memiliki prosentse $22 \%$ berada pada kategori hampir tidak Pernah, 41 orang dengan prosentase $41 \%$ berada pada kategori kadang-kadang, 29 orang dengan prosentase $29 \%$ beradaa dalam kategori cukup sering, 3 orang dengan prosentase $3 \%$ berada pada kategori selalu melakukan Daya tahan aerobik sebagai persiapan fisik sebelum mendaki gunung. Hasil hitung tabel daya tahan aerobik ditampilkan berupa gambar diagram garis sebagai berikut.

Dari hasil penelitian yang telah dilakukan tentang persiapan fisik pendakian gunung ijen diketahui hasil pengukuran yang diikelompokkan kedalam persiapan fisik daya tahan anerobik diketahui hasil hitung dan pengolahan data berdasarkan rumus yang sudah ditentukan sebagai berikut:

Tabel 4. Deskripsi Kategori Hasil Analsis Daya Tahan Anaerobik

\begin{tabular}{|c|c|c|c|c|}
\hline No & $\begin{array}{c}\text { Kelas } \\
\text { Interva } \\
1\end{array}$ & $\begin{array}{l}\text { Fre } \\
\text { que } \\
\text { nsi }\end{array}$ & $\begin{array}{l}\text { Prose } \\
\text { ntase }\end{array}$ & Kategori \\
\hline 1 & $6-10$ & 28 & $28 \%$ & $\begin{array}{l}\text { Tidak } \\
\text { Pernah }\end{array}$ \\
\hline 2 & $11-15$ & 29 & $29 \%$ & $\begin{array}{l}\text { Hampir } \\
\text { Tidak } \\
\text { Pernah }\end{array}$ \\
\hline 3 & $16-20$ & 29 & $29 \%$ & $\begin{array}{l}\text { Kadang } \\
\text { Kadang }\end{array}$ \\
\hline 4 & $21-25$ & 10 & $10 \%$ & $\begin{array}{l}\text { Cukup } \\
\text { Sering }\end{array}$ \\
\hline 5 & $26-30$ & 4 & $4 \%$ & Selalu \\
\hline
\end{tabular}

Dari hasil tabel 4 Persiapan Fisik daya tahan anerobik diatas dapat diketahui Tingkat aktifitas persiapan fisik pendaki sebanyak sebanyak 28 orang memiliki prosentase $28 \%$ berada pada kategori sangat tidak pernah, 29 orang memiliki prosentse $29 \%$ berada pada kategori hampir tidak Pernah, 29 orang dengan prosentase $29 \%$ berada pada kategori kadang-kadang, 10 orang dengan prosentase $10 \%$ beradaa dalam kategori cukup sering, 4 orang dengan prosentase $4 \%$ berada pada kategori selalu melakukan persiapan daya tahan anaerobik sebagai persiapan fisik sebelum mendaki gunung. Hasil hitung tabel daya tahan anaerobik ditampilkan berupa gambar diagram garis sebagai berikut.

Berdasarkan hasil analisis data yang dilakukan pada persiapan fisik pendakian gunung ijen dan gunung ranti terdapat hasil 79 orang dan 36 orang melakukan persipan pendakian gunung berupa akvitas fisik berjalan menyapu, bermain berjalan, lari, bersepeda. Bahkan selain itu yang dilakukan berdasarkan penuturan salah satu responden mengatakan melakukan aktivitas naik turun tangga karena dalam keseharian dan rutinitas kerja dikantor beliau melakukan aktivitas naik turun tangga. Hal ini sesuai dengan pendapat Hidayati (2018) aktivitas fisik keseharian dapat berpengaruh terhadap 
imunitas, pengendalian stress dan rekreasi pembentukan karakter, menguatkan otot serta aktifitas jalan mendapatkan kesenangan dan kepuasan, digunakan menjaga kebugaran tubuh.

Dari hasil analisis data berdasarkan persiapan fisik pendakian gunung di ijen dan ranti sebaian besar responden melakukan persiapan dengan intensitas latihan terstruktur dan terencana 67 orang dan 28 orang secara terstruktur dan terencana seperti menjaga istirahat teratur dan mejaga pola makan secara teratur dengan melakukan aktifitas fisik olahraga dipagi hari dan sore hari. Terkait hasil penelitian tersebut Indrayana (2012) mengatakan bahwa olahraga lari di alam terbuka dan daerah yang sesuai topografinya bermanfaat dapat meningkatkan performa dengan bentuk daerah yang bervariatif dan berubah ubah sehingga dapat mengurangi kelelahan dan meningkatkan kekuatan dan stamina. Jadi dengan kata lain melakukan olahraga secara teratur dan terstruktur sangat cocok diterapkan pada pendakian gunung ijen dan gunung ranti termasuk juga dengan menjaga pola makan dan istirahat yan cukup. Bahkan pendakian gunung dipercaya dapat mengilangkan stress dari padatnya rutinitas sehari-hari. Hal ini sesuai dengan pendapat dari Rahman dkk (2018) pendakian gunung bermanfaat untuk merevitalisasi, merefress, dan merelaksasi fikiran, serta sebagai media belajar atau hudup mandiri, mendapatkan pengalaman baru, dan dapat menjalin interkasi sosial terhadap sesama.

Dari hasil analis data berupa persiapan fisik daya tahan aerobik diketahui 79 orang dan 46 orang yang menjadi responden yang melakukan persiapan fisik berupa daya tahan aerobik diketahui aktifitas olahraganya berupa jalan kaki dan berolahraga lari dan jogging. bahkan dari penuturan beberapa dari responden melakukan aktifitas olahrga berupa bersepeda.dan naik turun tangga. Hal ini spendapat dengan Palar dkk (2015) latihan olahraga aerobik teratur dapat memperlancar aliran darah dan mempercepat pemulihan pada saat kelelahan dengan pembuangan zat-zat sisa metabolisme pada tubuh dengan kata lain detoxsifikasi dan Manfaat terhadap jantung bertambah besar, sehingga daya tampung lebih besar dan denyut nadi (stroke volume) menjadi kuat. Dari aktivitas fisik yang dilakukan responden terdapat kesesuaian dengan pendapat Adhidarma (2016) Yang nyatakan Harvart Step test atau aktivitas naik turun tangga dapat meninggkatkan kebugaran Kardiorespirasi. Jadi dengan kata lain persiapan fisik yang dilakukan 
responden bisa digunakan sebagai persipan fisik sebelum mendaki gunung.

Dari data yang didapat, berupa persiapan fisik daya tahan anaerob diketahui bahwa 57 orang responden dalam merpersiapkan diri sebelum pendakian terhitung sedikit dari hasil jawaban responden diantaranya pull up, push up sit up. Namun, selain itu ada juga faktor lain berdasarkan penuturan beberapa responden kita misalkan saja karena faktor kesibukan kerja dan kurangnya waktu luang yang membuat pendaki kurang mempersiapkan fisik sebelum pendakian, dengan kata lain kesadaran diri dari para pendaki sangatlah diperlukan. Sebab Nurajab (2019) menuturkan bahwa kegiatan mendaki memerlukan perencanaan yang matang dan faktor pendukung keberhasilan, pada pendakian gunung diantaranya adalah kebuaran fisik seorang pendaki gunung. Dengan begitu diketahui kesadaran diri pendaki asih kuran untuk persiapan fisik daya tahan anaerobik pendakian gunung ijen. jika dilihat dari topografi pendakian dari rute dan medan pendakian pada gunung ijen yang relative lebih lebar dan terdapat pos istirahat yang tidak terlalu jauh persiapan fisik anaerobik tidak terlalu dibutuhkan. Namun berdasarkan hasil analis, persiapan fisik aerobik lebih dibutuhkan untuk pendakian unun ijendaripada latihan fisik anaerobic hal itu berdasarkan bahwa pada jalur pendakian gunun ijen terdapat asap dan bau gas belerang.

Dari hasil persiapan fisik berupa latihan daya tahan anaerobik pada pendakian gunung ranti diketahui 28 orang responden dalam merpersiapkan diri sebelum pendakian terhitung banyak dari hasil jawaban responden diantaranya pull up, push up, sit up, dengan melakukan prsiapan anaerobic hal sependapat diutarakan Kholili (2018) latihan daya tahan otot anaerobik bertujuan untuk memperkuat otot tangan, lengan dan punggung sehingga tercipta keseimbangan dalam tubuh bagi calon pendaki. Dengan kata lain orang yang melakukan latihan fisik berupa anaerobik, dapat menambah kekuatan otot dan punggung hal ini juga sesuai dengan medan pada jalur pendakian gununga ranti yang memilki topografi jalur pendakian relative lebih sulit dengan medan pendakian lebih curam, berupa jalan setapak, dan berpasir sehingga persapan anaerobic sangat cocok di gunakan pada pendakian gunung ranti.

Selain persiapan fisik berupa aktifitas fisik, latihan fisik aerobik, anaerobik dengan menggunakan intensitas latihan sebagai persiapan fisik untuk pendakian gunung diantaranya melakukan persiapan fisik 
diantaranya menjaga kebugaran fisik dengan melakukan aktifitas jalan, lari, bersepeda dan menjaga pola makan, melakukan istirahat dan tidur yang cukup dirumah,. dari penuturan sebagian responden sebelum mendaki gunung juga memanjadkan doa sebelum memulai pendakian agar terhindar dari hal hal yang tidak di inginkan.

\section{KESIMPULAN}

Berdasarkan hasil penelitian dan pembahasan pada bab sebelumnya, diketahui kesadaran diri masyarakat untuk melakukan persiapan fisik sebelum mendaki gunung ditinjau dari aktivitas fisik, intensitas latihan, daya tahan aerobik pada pendakian gunung Ijen dan gunung Ranti berada pada kategori cukup melakukan persiapan fisik. namun pada persiapan fisik daya tahan anaerobik sedaran diri dari setiap individu terbilang masih kurang namun pada sub daya tahan anaerobik persiapan fisik pendaki terbilang pada kategori cukup melakukan persiapan fisik. dari hal ini juga diketahui betapa pentingnya kesadaran diri akan persiapan fisik pendakian gunung berupa latihan aerobik, latihan fisik anaerobik. Selain itu juga diketahui bahwasannya persiapan fisik pendakian gunung ijen yang cocok dengan melakukan persiapan fisik berupa aktifitas fisik, intensitas latihan dan latihan daya tahan aerobik, sedangkan pendakian gunung Ranti yang cocok berupa aktifitas fisik, intensitas latihan, latihan daya tahan aerobic, dan latihan daya tahan anaerobik.

\section{DAFTAR PUSTAKA}

Ardianto, F., Junaidi, A., \& Sugiarto. (2015). Profil Denyut Nadi Di Ketinggian Yang Berbeda Pada Pendaki Gunung Merbabu. Journal of Sport Sciences and Fitness. JSSF 4(2) ISSN 2252-6528. Universitas Negeri Semarang. http://journal.unnes.ac.id/sju/index.ph $\mathrm{p} / \mathrm{jssf}$.

Aditia, D. A. (2015). Survei Penerapan Nilai-Nilai Positif Olahraga Dalam Interaksi Sosial Antar Siswa Di Sma Negeri Se-Kabupaten Wonosobo Tahun 2014/2015. Journal of Physical Education, Sport, Health and Recreations. 4(12), ISSN 2252-6773. Universitas Negeri Semarang, Indonesia.

http://journal.unnes.ac.id/sju/index.ph p/peshr

Adidharma, N. C. (2016). Karakteristik Tingkat Kebugaran Kardiorespirasi siswa Kelas Kelas 6 SD di DesaMengwitani Tahun 2014. EJournal Medika, 5(5) ISSN: 23031395 Uneversitas Udayana. http://osj.unud. ac.id/index.php/eun.

Anggriawan, N. (2015). Peran Fisiologi Olahraga Dalam Menunjang Prestasi. Jurnal Olahraga Prestasi, 11(2), pISSN 0216-4493 e-ISSN 2597-6109 Universitas Negri Yogyakarta.

Anggundi, A., \& Sutarina, N. (2017). Manfaat Accelerometer Untuk Pengukuran Aktifitas Fisik. Jurnal 
olahraga prestasi, 13(1), ISSN 02164493. Universitas Indonesia, Jakarta. https://doi.org/10.21831/jorpres.v13i1 .12881

Alodokter, (2017) Hipoksia Kementrian Kesehatan Republik Indonesia ditinjau : Dr. Matianti. https://www.alodokter.com/hipoksia

Alodokter 2019 Hipotermia Kementrian Kesehatan Republik Indonesia ditinjau: Dr. Tjin Willy. https://www.alodokter.com/hipotermia Baharudin, L., \& hartoto, S. (2016). Hubungan Antara Aktivitas Olahraga Dengan Kemampuan Gerak Dasar Siswa (Studi Pada Siswa Kelas Vi, V Dan Vi Sd Negeri 7 Sidokumpul Gresik. Jurnal Pendidikan Olahraga dan Kesehatan. 4(1), ISSN : 2338798X. Universitas Negeri Surabaya. http://ejurnal.unesa.ac.id/index.php/jur nal-pendidikanjasmani/issue /archive.

Bangun, S. Y. (2016) Peran pendidikan jasmani dan olahraga Pada lembaga pendidikan di Indonesia. Jurnal Publikasi Pendidikan, Volume VI Nomor 3 ISSN: 2088-2092. Universitas Negeri Medan http://ojs.umm.ac.id/index.php/pubpen d.

Dewi, I. G., \& Wuryaningsih, C. E. (2019). Aktifitas Fisik Masyarakat Urban di Jakarta Selatan, Jurnal Of Midwifery, 1(1), ISSN 2654-3028. Universitas Indonesia.

http://dx.doi.org/10.35317/hajom.v1i1. 1790

Hidayati, R.W. (2018) The effeck of Footsteps Total to long labor. Journal of Health Studies, Vol. 2, No. 1, ISSN online: 2549-3353, Universitas Aisyiyah Yogyakarta, DOAJ: http://doaj.org/toc/2549-3353

Fenanlampir, A., \& Faruq, M. M. (2015). Tes dan Pengukuran Dalam Olahraga. ISBN 978-373-29-5416-6, Penerbit:
Cv Andi OffsetJl. Beo 39-40, Yogyakarta 552821

Indrayana, B. (2012). Perbedaan Pengaruh Latihan Interval Training Dan Fartlek Terhadap Daya Tahan Kordiovaskuler Pada Atlet Junior Putra Teakwondo Wild Club Medan 2006/2007. Jurnal Cerdas Sifa, 1(1). Universitas Jambi. https://scholar.google.com/scholar?clu ster

$=14186066601002081732 \& h l=i d \& a s$ $\mathrm{sdt}=0,5 \&$ sciodt $=0,5$

Infodatin, (2015). Pembinaan Kesehatan Olahraga di Indonesia. ISSN 24427659 Pusat Data dan Informasi Kementrian Kesehatan Republik Indonesia.

https://pusdatin.kemkes.go.id/folder/vi ew/01/structure-publikasi-pusdatininfo-datin.html

Ilmiyanto, F., \& Budiwanto, S. (2017). Perbedaan Pengaruh antara Metode Latihan Fartlek dan Metode Latihan Continuous Tempo Running Terhadap Peningkatan Daya Tahan Kardiovaskuler Peserta Latihan Lari Jarak Jauh. jurnal Indonesia Performance, 1(2), ISSN 2597-3624. Universitas Negeri Malang. http://journal2.um.ac.id/index.php/jko

Iswahyuni, S. (2017). Hubungan Antara Aktifitas Fisik Dan Hipertensi Pada Lansia. Jurnal Profesi, 14(2), ISSN 2548-9933. Mamba'ul Ulum Surakarta. http://dx.doi.org/10.26576/profesi.155

Sandi, I. N. (2019). Sumber Dan Metabolisme Energi Dalam Olahraga. Jurnal Pendidikan Kesehatan Rekreasi. 5(2), P-ISSN 2337-9561, E-ISSN 2580-1430. Fakultas Matematika dan Ilmu Pengetahuan Alam Universitas Udayana.

Kaprawi, T., Moningka, M., \& Rumampuk, J. (2016). Perbandingan Saturasi Oksigen Pada Orang Yang Tinggal Di 
Pesisir Pantai Dan Yang Tinggal Di

Daerah Pegunungan. Jurnal eBiomedik (eBm), 4(1), ISSN 2337330X Universitas Sam Ratulangi Manado. https://doi.org/ 10.35790/ebm.4.1.2016.10816

Kostermans, D. (2016). Peranan Olahraga Tradisional Terhadap Pelestarian Adat Dan Budaya. 1(1), Universitas 17 Agustus $\quad 1945 \quad$ Samarinda https://doi.org/10.31293/lg.v1i1.2415

Kemenkes (2018) Mengenal Jenis Aktifitas Fisik, Direktorat Promosi kesehatan dan Pemberddayaan Masyarakat. Kementrian Kesehatan Republik Indonesia

http://promkes.kemkes.go.id/content/? $\mathrm{p}=8807$

Kemenkes (2019) Apa Definisi Aktivitas Fisik, Direktorat Jendral pencegahan dan pengendalian penyakit Tidak Menular, Kementrian Kesehatan Republik Indonesia. http://p2ptm.kemkes.go.id/infographic -p2ptm/apa-definisi-aktifitas-fisik

Kemenkes (2018) Kebutuhan Tidur Sesuai Usia. Pencegahan Penanggulangan Penyakit Tidak Menular. Kementrian Kesehatan Republik Indonesia www.p2ptm.Kemkes.go.id

Lailissaum, A., Kahar, S., \& Hani'ah H. (2013). Pembuatan Peta Jalur Pendakian Gunung Merbabu. Jurnal Geodesi Undip. 2(4), ISSN : 2337$845 \mathrm{X}$.

https://ejournal3.undip.ac.id/index.php /geodesi/article/view/3705.

Lusiani, T., \& Qoiriyah, A. (2014). Sistem Pakar untuk Menentukan Menu Makanan Sehat pada Penderita Diabetes Mellitus. Jurnal Ilmu Komputer dan Ilmu Sains Terapan. 5(1), ISSN 2087-0140. STMIK Surabaya / STIKOM Surabaya. https://doi.org/10.31598/sacies.v5i1.59
Mairizal, Y., \& Rusmana, R. (2018) Perbandingan Latihan Pull Up dan Latihan Push Up Terhadap Keterampilan Chest Pass Bola Basket. Jurnal Kepelatihan Olahraga. 10(1), ISSN 2086-229X. STKIP Pasundan Cimahi.

http:/ejurnal.upi.edu/index.php/JKO/ar ticle/view/16277/9128

Maksum, A. (2012). Metodologi Penelitian Dalam Olahraga. ISBN 9789790284838 Unesa University Press. Surabaya

Nurajab, E. (2019). Hubungan Tingkat Kebugaran Jasmani dengan Aklimatisasi Pendaki Gunung. Jurnal Olahraga JO, 5(1) ISSN 2442-9961 STKIP Pasundan, Indonesia. http://jurnalolahraga.stkippasundan.ac. id/index. php/jurnalolahraga.

Noor, J. (2014). Metodologi Penelitian: Skripsi, Tesis, Disertasi, dan Karya Ilmiah. Perpustakaan Nasional Dalam Terbitan ISBN 978-602-3730-82-2 Penerbit KencanaPrenadamedia Group J1.Tambara Raya No 23 Rawamangun Jakarta 13220

Noorhasanah, E. (2017). Perbedaan Pengaruh Aktivitas Latihan Aerobik Ringan Dan Sedang Terhadap Kadar Sitokin Proinflamasi Tumor Necrosis Factor (Tnf-A) Pada Remaja. Jurnal Caring nursing, 1(1), ISSN 25800078. Universitas Muhammadiyah Banjarmasin. https://journal.umbjm .ac.id/index.php/caringnursing/article/view/2/2

Pramudya, R. A., \& Hidayat, S. (2017). Perancangan Buku Panduan Mendaki Gunung Untuk Pemula e-Proceeding of Art \& Design : 4(3) ISSN : 23559349 Universitas Telkom. https://repository.telkomuniversity.ac. id/home/information/id/134.html. 
Palar, C. M., Wongkar, D., \& Ticoalu S. H. R. (2015). Manfaat Latihan Olahraga Aerobik Terhadap Kebugaran Fisik Manusia. Jurnal e-Biomedik (eBm), 3(1), ISSN 2337-330X. Universitas Sam Ratulangi Manado. https://doi.org/10.35790/ebm.3.1.2015 .7127

Pinem, W. (2018). Tips Mendaki Gunung. Publikasi Seni Berfikir, Kebon Kacang Sentral Jakarta 10240

Purwantara, S. (2015) Studi Temperatur Udara Terkini Di Wilayah Di jawa Tengah dan DIY. Geomedia, 13(1), Universitas Negeri Yogyakarta. https://doi.org/10.21831/gm.v13i1.447 6

Pane, B. S. (2015). Peranan Olahraga Dalam Meningkatkan Kesehatan. Jurnal pengabdian kepada masyarakat, 21(79), ISSN 0852-2715, Universitas Negri Medan. https://doi.org/10.24114/jpkm.v21i79. 4646

Putri, R. A., \& setiawati, E. (2017). Pengaruh Sirkuit Training Terhadap Indek Massa Tubuh Pada Anak Obesitas. Jurnal Kedokteran Diponegoro, 6(1), ISSN 2540-8844, Universitas Diponegoro. http://ejournal3. undip.ac.id/index.php/medico

Philips dan d'orso 2010 body for life. Harper Collins publishers, ISBN 978979-024-557-0 www.opuspress.com

Rahman,F. A., Sugianto, \& Kristianto, A. (2018). Mountaineering Physical activities as Community Receational Sports. Jurnal pendidikan: teori penelitian dan pengembangan, 3(3), ISSN 2502-471X, Universitas Sebelas Maret. http://journal.um.ac.id/index.php/jptpp I

Rosidin, U., Sumarni, N., \& Suhendar, I. (2019). Penyuluhan Tentang Aktifitas
Fisik dalam Peningkatan Status Kesehatan, Jurnal Medika Karya, 2(2), ISSN 2621-9026 Universitas Padjadjaran. https://doi.org/10.24198/ mkk.v2i2.22574

Saleh, Y. A.R., \& Nurhayati, F. (2014) Perbedaan Kemampuan Daya Tahan Jantung dan Paru-paru antara Siswa Kelas XI Pada Pembelajaran Pendidikan Jasmani Pagi Hari Dengan Siang hari di SMA 1 Kediri. Jurnal Pendidikan Olahraga dan Kesehatan, 2(1) ISSN 2338-798X Universitas Negeri Surabaya. http://jurnalmahasiswa.unesa.ac.id /index.php/jurnalpendidikanjasmani/article/view/2842

Setiyawan, (2017). Visi Pendidikan Jasmani dan Olahraga. Jurnal Ilmiah Penjas, Vol.3 No.1, ISSN : 2442-3874. Universitas PGRI Semarang. http://202.91.10.29/index.php/JIP/artic le/view/543.

Sugiono, (2014). Cara Mudah Menyusun Skripsi, Tesis, dan Disertasi. ISBN 978-602-7825-84-0 Penerbit Alvabeta, cv. Jl. Gegerkalong Hilir No. 84 Bandung. www.cvalfabeta.com

Sahary, M. I. (2015). Kajian Risiko Cedera dan MasalahUmum Pendaki Mahasiswa Univeesitas Udayana. Jurnal Intisari Sains Medis, 2(1), ISSN 2089-9084. Universitas Udayana. http://demo.ejournals.ca/ isainsmedis.id/index.php/ism/article/vi ew/84

Siahaan, R. F. (2017). Mengawal Kesehatan Keluarga Melalui Pemilihan dan Pengolahan Pangan Yang Tepat. Jurnal Keluarga Sehat Sejahtera 15(2) ISSN: 1693-1157. Pusdibang-KS UNIMED

Susilo, T. (2012). Siap Mendaki. Panduan Dasar Kegiatan Pendakian, Jejak Pendaki 
Sulastri, R., Mariati, S., \& Syamsuar. (2018) Program Latihan Jogging Dengan Treadmill Terhadap Denyut Nadi Istirahat Pada Ibu Ibu anggota Fitness Centre Yayasan Indonesia. Jurnal Sain Olahraga dan Pendidikan Jasmani. 18(1) ISSN 114-562X Universitas Negri Padang, Indonesia. http://sportscience.ppj.unp.ac.id/index. $\mathrm{php} / \mathrm{jss} / \mathrm{index}$

Sulikan, (2018) Pengaruh Peregangan Pemanasan dan Pemanasan Peregangan Terhadap Kecepatan Lari 54,86 Meter (60 Yard). Jurnal Filsafat, Sains, Teknologi, dan Sosial Budaya. 24(2), ISSN 0852-3181. IKIP Budi Utomo Malang. https://doi.org/10.33503/paradigma. v24i 2.468

Undang-Undang Republik Indonesia Nomor 3, Tahun (2005). Tentang Sistem Keolahragaan Nasional.

Yudhiana, Subardjah, Juliantine 2012 Latihan Fisik FPOK Universitas Pedidikan Indonesia

Yudhi, Suprayogi, Yuwono (2018) Pembuatan Peta Jalur Pendakian Gunung Lawu. Jurnal Geodesi Undip, 7(4), ISSN 2337-845X. Universitas Diponegoro. doi:10.15562/ism.v2i1.84

Welis, W., \& Rifki, M,. S. (2013). Gizi Untuk Aktivitas Fisik Dan Kebugaran. ISBN; 978602165002 8. Universitas Negri Padang. http://repository.unp.ac.id/id/eprint/48 9 